Vol. 15(19), pp. 786-797, 11 May, 2016

DOI: 10.5897/AJB2015.15104

Article Number: 5EF491C58427

ISSN 1684-5315

Copyright (c) 2016

Author(s) retain the copyright of this article

http://www.academicjournals.org/AJB

\title{
Inhibition of cell death as an approach for development of transgenic resistance against Fusarium wilt disease
}

\author{
Betty Magambo ${ }^{1 *}$, Khanna Harjeet ${ }^{2}$, Geofrey Arinaitwe ${ }^{1}$, Sali Tendo ${ }^{1}$ Ivan Kabiita Arinaitwe ${ }^{1}$, \\ Jerome Kubiriba ${ }^{1}$, Wilberforce Tushemereirwe ${ }^{1}$ and James Dale ${ }^{2}$ \\ ${ }^{1}$ National Agricultural Research Laboratories, National Agricultural Research Organisation (NARO) Kampala, Uganda. \\ ${ }^{2}$ Queensland University of Technology Brisbane, Australia.
}

Received 16 November, 2015; Accepted 18 February, 2016

\begin{abstract}
Fusarium oxysporum f. sp. cubense (Foc) is one of the major threats to dessert banana (Musa spp.) production. In Uganda, 'Sukali Ndiizi' is one of the most popular dessert banana cultivars and it is highly susceptible to Fusarium wilt. Development of resistant cultivars through transgenic approaches has shown to offer one of the most effective control options for most diseases. The transgenic approaches for providing plant disease resistance have mainly been through either enzymatic destruction of pathogen structures, neutralization of pathogen and its products or production of metabolites that eventually kill the pathogen. However in recent years, methods that prevent cell death of host plant after infection especially for necrotrophic pathogens like $F$. oxysporum have registered success in providing resistance in several crops. We investigated whether the transgenic expression of a programmed cell death inhibition gene in Sukali Ndiizi could be used to confer Fusarium resistance to Foc race 1. Embryogenic cell suspensions of cv. 'Sukali Ndiizi, were stably transformed with a synthetic, plant-codon optimise $\mathrm{mCed}-9$ gene. Twenty-eight independently transformed plant lines were regenerated. The lines were inoculated with Foc race 1 and observed for 13 weeks in small-plant glasshouse. Three transgenic lines showed significantly lower internal and external disease symptoms than the wild-type susceptible 'Sukali Ndiizi' banana plants used as controls. This is the first report from Africa on the generation of Fusarium wilt tolerant transgenic 'Sukali Ndiizi', a very popular but rapidly diminishing African dessert banana.
\end{abstract}

Key words: Fusarium wilt, banana, Sukali Ndiizi, Fusarium oxysporum f. sp. Cubense race 1, programmed cell death, disease resistance.

\section{INTRODUCTION}

Fusarium wilt, was first reported in Uganda in 1952 (Leaky, 1970) and it continues to be a major threat to dessert banana production in Africa and worldwide
(Ploetz and Pegg, 2000). This disease is caused by a soil-borne fungal pathogen Fusarium oxysporum forma specialis (f. sp.) cubense (Foc) that affects the root

*Corresponding author. E-mail: bettymagambo@gmail.com.

Author(s) agree that this article remains permanently open access under the terms of the Creative Commons Attribution License 4.0 International License 
system hampering nutrient and water supply to the plant. Insufficient supply of nutrients eventually leads to wilting and death of plants. Based on Foc variation in virulence to specific host cultivars, four physiologically distinct 'races' have been identified. The race predominant in Uganda is race 1 (Kangire et al., 2001). East African highland bananas (AAA-EA) are resistant to (Foc race 1), but the popular dessert banana Sukali Ndiizi (AAB genome), Bogoya (Gros Michel) (AAA) and the juice bananas Kisubi (ABB) and Kayinja (ABB) are susceptible to Foc (race 1). Sukali Ndiizi is a small sweet banana characterized by having a compact bunch, short fruit fingers which are very sweet when ripe. It is a widely distributed cultivar and is gaining importance as a potential export commodity for Kenya and Uganda for both local and export markets (Tushemereirwe et al., 2001; Van Asten et al., 2008). Fusarium wilt has rapidly spread over the past decades in the region and has now become a major constraint to the production of Sukali Ndiizi causing losses up to $100 \%$ in some farms (Tushemereirwe et al., 2001).

At present, there are no cultural or chemical methods available that can effectively and sustainably control Foc (Ploetz, 2015). Fusarium chlamydospores remain viable in the soil for decades, leaving the infested fields unsuitable for growing susceptible banana cultivars. The only sustainable option for controlling this disease is through the use of resistant cultivars generated either by conventional breeding or through genetic modification. This option needs availability of resistance genes and some sources of resistance to Foc have been identified in a few wild bananas cultivars (Ploetz, 2006). Genetic engineering to enhance antifungal resistance through over-expression of genes that code for anti-fungal proteins or other diseases has emerged as a very promising strategy and has been tested in many crop plants (Collinge et al., 2010; Punja, 2001; Grover and Gowthaman, 2003). Development of Foc resistance in banana through genetic engineering may be supported by the availability of efficient and reliable banana transformation protocols (Khanna et al., 2004; Becker et al., 2000).

Different strategies have been used to identify gene products that can be expressed in transgenic tissues to counter the attack from plant pathogens. They involve destruction of pathogen structures such as chitin or glucan, neutralization of pathogen products and production of metabolites that eventually kill the pathogen, (Punja, 2001). The antimicrobial peptide (Ace$A M P 1)$ gene derived from onion seeds was able to confer resistance to banana cultivar Rasthali after infection with Foc race 1 under a screen house evaluation (Mohandas et al., 2013). The neutralizing effects result from induced innate responses that involve production of defensins, phytoalexins or through signalling molecules that are initiated by $R$ genes (Girhepuje and Shinde, 2011). Use of Programmed Cell Death (PCD) genes is one other way that has been successfully used to provide resistance against necrotrophic fungal pathogens (Gaolathe and Arunika, 2015). Human $B c l-x L$ and nematode Ced9 genes have been shown to increase tolerance of tomato to cucumber mosaic virus (Ping et al., 2004). Constitutive expression of various anti-apoptotic $\mathrm{BCl}-2$ gene family members (including $B c l-x L$, Ced-9 and $B c l-23^{\prime}$ UTR) in transgenic tobacco plants resulted in high levels of resistance to a broad range of necrotrophic fungi (Dickman et al., 2001). This research has previously shown that when banana cell suspensions are exposed to soil pathogen, Agrobacterium tumefaciens, extensive cell death follows. This is accompanied by DNA laddering and fragmentation and the formation of apoptotic-like bodies (Khanna et al., 2007). These cellular responses were also inhibited in cells expressing the anti-apoptosis genes $B c l-x L, B C l-23^{\prime}$ UTR and Ced-9.

A native banana MusaBAG1 and a nematode antiapoptosis gene Ced9 have conferred Foc race 1 resistance in transgenic banana cultivar 'Rasthali' and 'Lady Finger' respectively (Ghag et al., 2014; Paul et al., 2011). It was therefore hypothesized that a synthetic, plant codon-optimized version of $\mathrm{Ced} 9$ ( $\mathrm{mCed} 9$ ) may also be able to confer Foc race 1 resistance to cv. Sukali Ndiizi. In this paper we demonstrate transgenic resistance in cv. Sukali Ndiizi to Foc race 1 conferred by $\mathrm{m}$ Ced9 genes under glasshouse conditions.

\section{MATERIALS AND METHODS}

Binary vector pYC11 was generated by cloning a synthetic, plantcordon optimised mCed-9 gene under control of the maize polyubiquitin (Ubi-1) constitutive promoter in pCambia2300 that also has the plant selection marker gene, nptIl under the control of constitutive CaMV 35S promoter in the T-DNA region. Embryogenic cell suspensions (ECSs) of the banana cultivar 'Sukali Ndiizi (Musa spp. $A A B$ group) were initiated and maintained as previously described (Namanya et al., 2004). The ECS were transformed with pYC11 construct using Agrobacterium-mediated transformation protocol as previously described (Khanna et al., 2004) with slight modifications. Briefly, a single confirmed colony of AGL1/pYC11 was inoculated in $10 \mathrm{ml}$ of Yeast mannitol broth media containing selectable antibiotics and incubated for 3 days at $28^{\circ} \mathrm{C} .5 \mathrm{ml}$ of this culture was incubated in $20 \mathrm{ml}$ of LB with shaking overnight at $28^{\circ} \mathrm{C}$. The bacterial culture was centrifuged at $5000 \mathrm{rpm}$ for $10 \mathrm{~min}$ and the pellet re-suspended and induced for $3 \mathrm{~h}$ in bacterial resuspension media TMA1 supplemented with $200 \mu \mathrm{M}$ acetosyringone and shaking at $70 \mathrm{rpm}$, room temperature for $4 \mathrm{~h}$. After 3 days of co-cultivation in the dark, infected ECS were washed with liquid MA2 medium supplemented with $200 \mu \mathrm{g} \mathrm{ml}^{-1}$ Timentin $\AA$ for killing the Agrobacterium. The cells were then plated on glass filter paper and transferred to semi-solid embryo germination media supplemented with $200 \mathrm{\mu g} \mathrm{ml}^{-1}$ Timentin $\AA$, 100 $\mu \mathrm{g} \mathrm{ml}^{-1}$ kanamycin and kept at $25^{\circ} \mathrm{C}$ in the dark. The cells on glass filters were sub-cultured on fresh media every 14 days while being observed for embryo development. Mature embryos were transferred to germination medium MA4 supplemented with $200 \mu \mathrm{g}$ $\mathrm{ml}^{-1}$ Timentin and $100 \mu \mathrm{g} \mathrm{ml}^{-1}$ kanamycin. The germinated shoots were then transferred to MS to enable root formation. Well rooted plantlets were put on multiplication media with sub-cultures every month to get 10 clones for every line. These plants were transferred to the glass house and kept in the humid chamber for 2 weeks before being transferred to bigger pots of $200 \mathrm{~mm}$ diameter. The 
plants were left to attain a height of 10 to $15 \mathrm{~cm}$ before Foc bioassays were carried out.

\section{Molecular characterization of transgenic plants}

Leaf samples were collected and total genomic DNA extracted using the modified CTAB protocol (Grover and Gowthaman, 2003). Briefly, $1 \mathrm{~g}$ of leaf tissue was ground in liquid nitrogen and incubated in $700 \mu \mathrm{l}$ of CTAB extraction buffer at $65^{\circ} \mathrm{C}$ for $30 \mathrm{~min}$. The total DNA was extracted using $700 \mu \mathrm{l}$ of chloroformisoamylalcohol $(24: 1) \mathrm{v} / \mathrm{v}$ and precipitated using an equal volume of isopropanol. After washing the pellet with $1 \mathrm{ml}$ of $70 \%$ cold ethanol, the DNA was treated with RNase A, re-extracted and reprecipitated. The final precipitate was washed and re-suspended in sterile water. To detect the presence of mced9 and nptll gene sequence primer pairs. $\mathrm{PCR}$ was done with a reaction that contained $50 \mathrm{ng}$ of plant DNA, $1.2 \mathrm{mM} \mathrm{MgCl}_{2}, 0.4 \mu \mathrm{M}$ of each of the primer pairs, 1x PCR buffer, $0.24 \mathrm{mM}$ dNTPs and 0.02 Unit Taq per reaction of $20 \mu \mathrm{l}$. The reaction mixture was subjected to an initial denaturation step of $95^{\circ} \mathrm{C}$ for 2 min followed by 30 cycles of $94^{\circ} \mathrm{C}$ for $30 \mathrm{~s}$; annealing temperatures of $55^{\circ} \mathrm{C}$ for $30 \mathrm{~s} ; 72^{\circ} \mathrm{C}$ for 2 min and a final extension step of $72^{\circ} \mathrm{C}$ for $5 \mathrm{~min}$. The PCR products were run on $1 \%$ agarose. For RT-PCR analysis, RNA was extracted from $100 \mathrm{mg}$ of fresh leaf tissue using an RNeasy Plant Mini kit (Qiagen, Valencia, CA) following the manufacturer's instructions and was treated with RNase-free DNase (Promega, Madison, WI). Two-step RT-PCR was performed using RNA to cDNA EcoDry ${ }^{\text {TM }}$ premix protocol (Clonetech, Shiga, Japan), a pre-aliquoted, dry master mix, for reverse transcription, followed by normal PCR amplication with the appropriate gene-specific primers. The southern analysis of transgenic plants was essentially done as described by Khanna et al. (2007).

\section{Fungal cultures and inoculum preparation}

F. oxysporum f. sp. cubense race 1 (VCG 0124) isolate was obtained from plant pathology laboratories at NARO, Uganda. The fungus was inoculated on full strength potato dextrose agar (PDA) supplemented with $200 \mathrm{\mu g} \mathrm{ml}^{-1}$ ampicillin and incubated for 7 days at $27^{\circ} \mathrm{C}$. Millet grain (Echinochloa esculenta) was rinsed in tap, soaked overnight and rinsed with distilled water before autoclaving at $121^{\circ} \mathrm{C}$ for $1 \mathrm{~h}$. Five potato dextrose agar stabs of $1 \mathrm{~mm}^{3}$ were taken from a uniformly growing fungal culture using a sterile blade and inoculated into $250 \mathrm{~g}$ of cooled sterile millet grain. The cultures were incubated at room temperature $\left(23\right.$ to $\left.25^{\circ} \mathrm{C}\right)$ and mixed daily for 10 days to ensure even distribution of the growing fungus.

For quantifying different spore concentrations, Foc race 1 was grown on full strength PDA and incubated for 7 days at $27^{\circ} \mathrm{C}$. Mycelium of grown Foc race 1 was first harvested by scraping using a sterile blade and placed in a falcon tube with $20 \mathrm{ml}$ of sterile water. The contents were mixed vigorously and filtered through a sterile nylon mesh to separate the mycelium from the spores. The spores in the filtrate were washed twice in $20 \mathrm{ml}$ of water, centrifuged at $1000 \mathrm{rpm}$ and suspended in $1 \mathrm{ml}$ of sterile water. The conidia concentration in the suspension was determined with a haemocytometer and concentration adjusted to $2 \times 10^{4}$ spores $\mathrm{ml}^{-1}$ and $2 \times 10^{6}$ spores $\mathrm{ml}^{-1}$. For millet inoculation, $50 \mathrm{ml}$ of each spore concentration was added to $250 \mathrm{~g}$ of sterile millet and 5 agar stabs were also used for this experiment.

\section{Small-plant bioassay}

Twenty-eight lines of tissue-cultured transgenic plants (5 to 10 clones per line) of the 'Sukali Ndiizi cultivar and five wild-type tissue-cultured banana plants of 'Sukali Ndiizi were acclimatized and transplanted into $100-\mathrm{mm}$ diameter pots in sterile soil for 8 weeks in a glasshouse at $27^{\circ} \mathrm{C}$ under natural light conditions.

Selected transgenic banana lines and wild-type control plants were potted into $200 \mathrm{~mm}$ pots with sterile soil and inoculated with five mycelia agar stabs of Foc race 1 in a glasshouse trial. Plants were maintained with regular watering and fertiliser regime in a greenhouse with an average temperature between 25 and $27^{\circ} \mathrm{C}$.

\section{Assessment of disease symptoms}

Twelve weeks after inoculation, external and internal symptoms of Fusarium wilt infection were assessed using a modified version of the method described by Mak et al. (2001). External symptoms of the Fusarium wilt were assessed by scoring each plant for the intensity of the three main disease symptoms (Table 2). This was based on a modified version of the method described by Mak et al. (2001). Yellowing and wilting were assessed using a 5-point scoring scale where 1 = healthy, no sign of symptoms, 2 = slight symptoms, mainly on lower leaves, 3 =advanced symptoms ( 50\%), $4=$ extensive symptoms $(\sim 90 \%)$ and $5=$ entire plant affected (dead plant). Splitting of the stem was assessed using a 3-point scoring scale where $1=$ no sign of splitting, 2 = slight splitting at the base of the plant and $3=$ extensive splitting. These point scale values determined the Leaf symptom index (LSI) of the cultivar or line.

For assessing the internal symptoms, plants were removed from the pots and the pseudostem was removed, leaving behind the corm and the root region. The plants were washed to remove soil from the roots then split longitudinally through the corm. Scores for corm infection intensity were made and an 8-point scale was used to compare the level of discolouration and to get the corm discolouration index (RDI). The LSI and RDI were used to obtain the disease severity index (DSI) that was used to determine susceptibility or resistance levels of the cultivar.

\section{Statistical analysis}

For pathogenicity test experiments, the Disease Severity Index of each cultivar and transgenic line was computed from the LSI and the RDI according to Mak et al. (2001).

$\mathrm{DSI}=\frac{\Sigma(\text { No.of scale } \mathrm{x} \text { No.of plantlets in the scale })}{\Sigma(\text { No of treated plantlets })}$

Plants with DSI scale of 1 for both LSI and RDI were classified as resistant. Plants with DSI scale between 1.1 and 2 for LSI and between 1.1 and 3 for RDI were classified as tolerant. Susceptible plants had DSI scale between 2.1 and 3 for LSI and between 3.1 and 5 for RDI. Highly susceptible plants had DSI scale higher than 3 for LSI and higher than 5 for RDI.

The data generated for the transgenic lines was analyzed using DSI values and ANOVA using the Genstat software (14th edition). Significance was determined using Dunnett's test $(p<0.05)$.

\section{RESULTS}

\section{Transformation and regeneration of transgenic plants}

Embryogenic cell suspensions of 'Sukali Ndiizi' transformed with binary vector pYC11 were selected on kanamycin and the effectiveness of selection was evident within the first three weeks as the untransformed cells started turning brown and dying. Transformed cells 

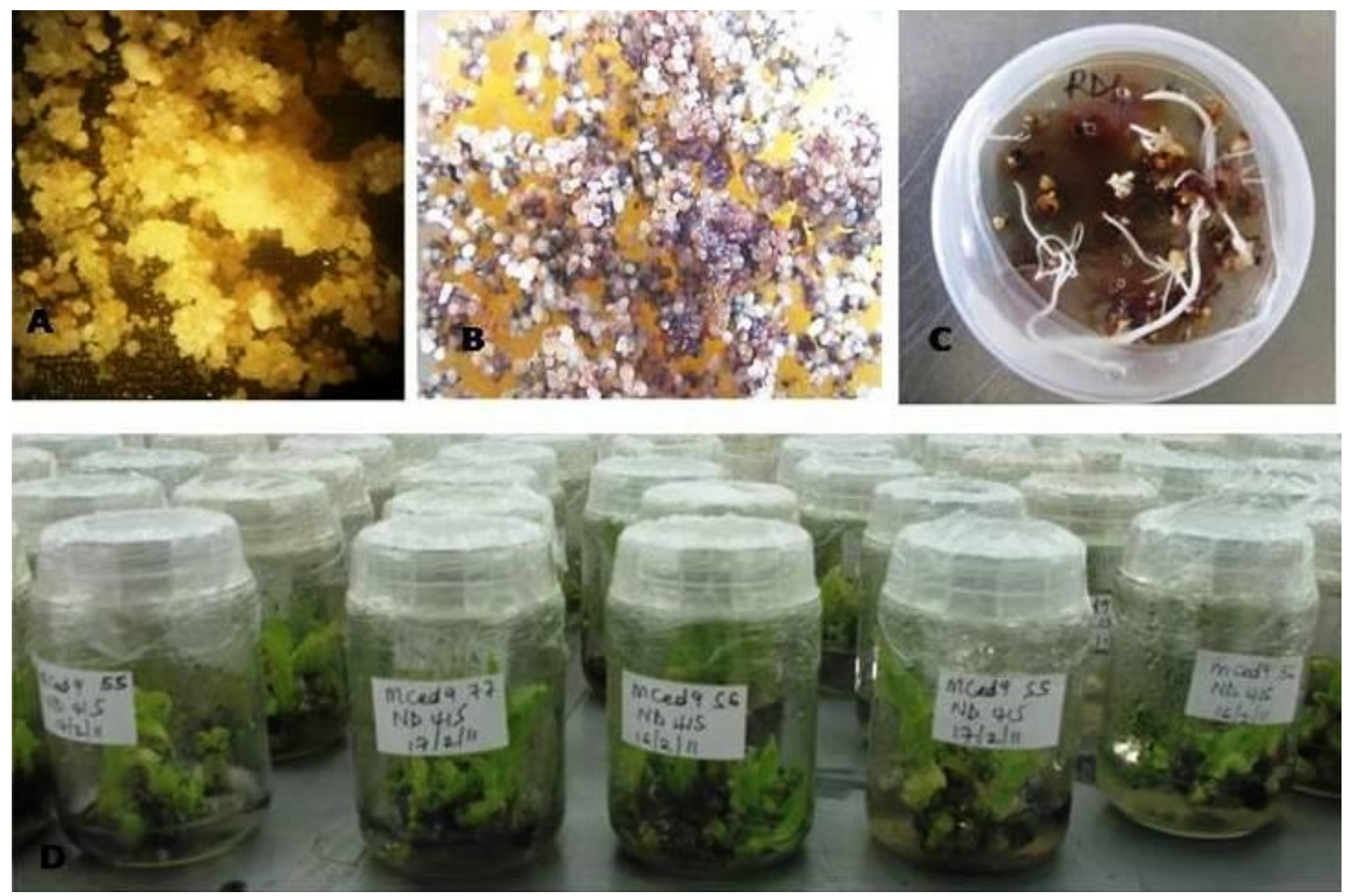

Figure 1. Selection and regeneration of cells transformed with mCed9. (A) Cells on selection media (MA3). (B) Developed embryos on selection media (MA3). (C) Mature embryos on selection media (RD1) (D) Developed shoots on multiplication medium.

developed into small white embryos which increased in size and matured over a period of two months. Matured embryos started germinating within 3 weeks when transferred to the germination media. A total of 84 embryos germinated and 69 shoots regenerated into plants (Figure 1).

\section{Molecular characterisation}

Total genomic DNA was extracted from the 69 putative transgenic plants. In case of the lines that were positively transformed, primers specific for nptll amplified the expected product size of $620 \mathrm{bp}$ and primers specific for mCed9 produced a band of the expected product size of $291 \mathrm{bp}$ (Figure 2). A total of 42 lines tested were positive for both $n p t / l$ and $\mathrm{m} C e d 9$ transgenes.

From these 42 lines, total RNA was extracted from leaf tissues and a two-step RT-PCR was performed using primers specific for $\mathrm{mCed} 9$ and all lines produced a band of the expected product size of $291 \mathrm{bp}$ (Figure 3).

Nine transgenic lines $4,12,20,21,27,55,72,83$ and 96 were selected for southern analysis to determine the copy number of the transgene (Figure 4). The selected lines were a representation of those that were susceptible $(4,12,21)$ and those that were tolerant line $(27,55,72$, $83,96)$ after screening with Foc 1 . Copy number ranged from 1 to more than 3 . Line 20 had two copies while line 55 and 83 had one. There was no direct correlation observed between transgene copy number and level of tolerance to Fusarium infection.

\section{Glasshouse trials}

\section{Pathogenicity of Foc race 1 isolate}

It has previously been confirmed that East African highland banana cultivars (e.g. Nakinyika) are resistant to Foc race 1 while 'Sukali Ndiizi' is susceptible under field conditions (Kangire et al., 2001). When 10 tissue cultured plants each from these two cultivars were infected, the Foc race 1 isolate used in this study was able to infect both cultivars. Sukali Ndiizi was severely infected even at $2 \times 10^{4}$ spores $\mathrm{ml}^{-1}$ spore concentrations while Nakinyika showed only mild symptoms even at the concentration of 

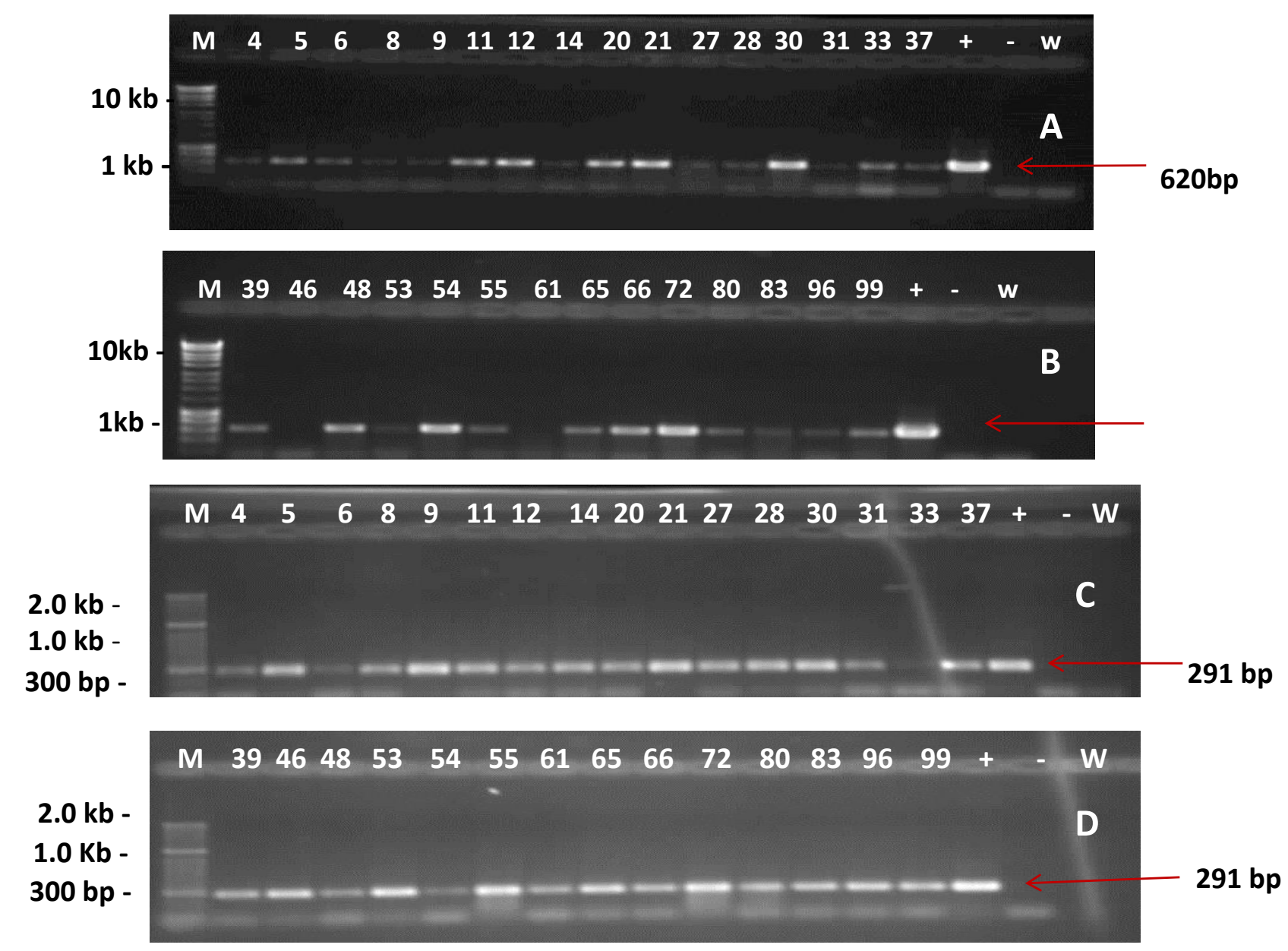

Figure 2. Representative PCR of transgenic Sukali Ndiizi lines transformed with pYC11. (A and B) Amplification of nptll. (C and D) Amplification of mCed9. Lanes 4 to 37 and 39 to 99 are test plants; + is plasmid DNA control, - is non-transformed control plant, W: water control, M: Hyper ladder I molecular marker for A and B gels, Hyper ladder II molecular marker for C and D gels.

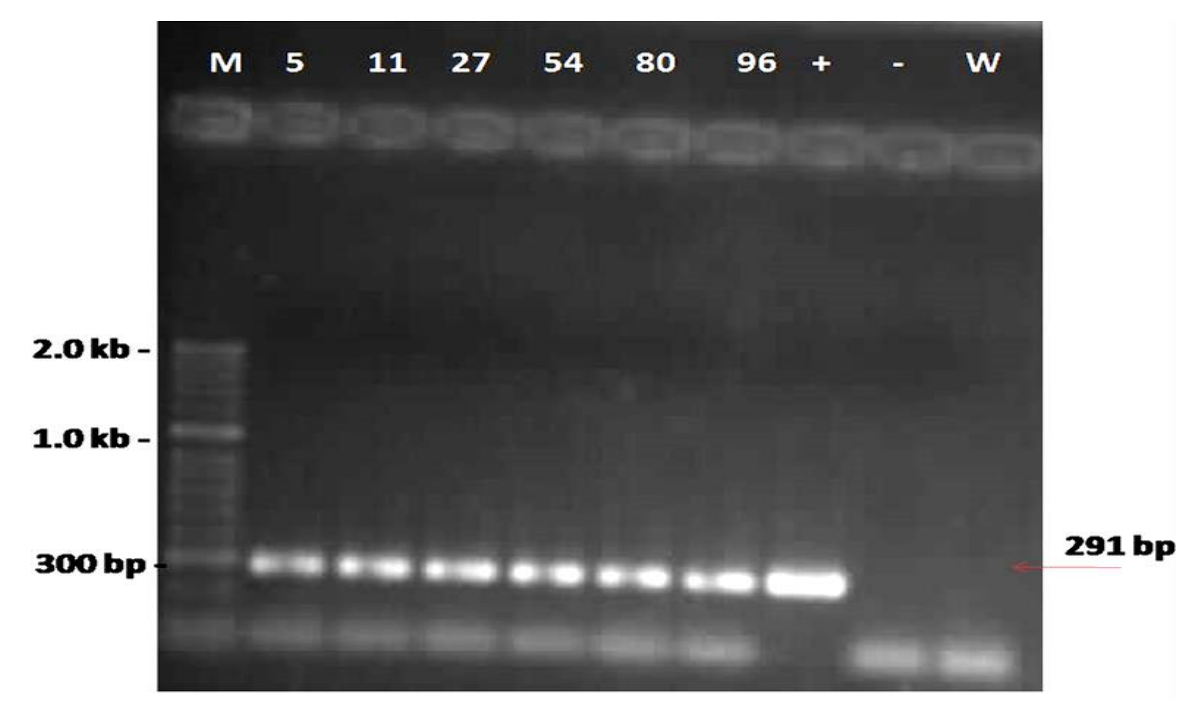

Figure 3. RT-PCR of selected transgenic Sukali Ndiizi lines transformed with pYC11. Lanes 5 to 96 are test plants +: Plasmid DNA, - : Non-transformed control plant, W: Water control, Hyper ladder II molecular marker. 

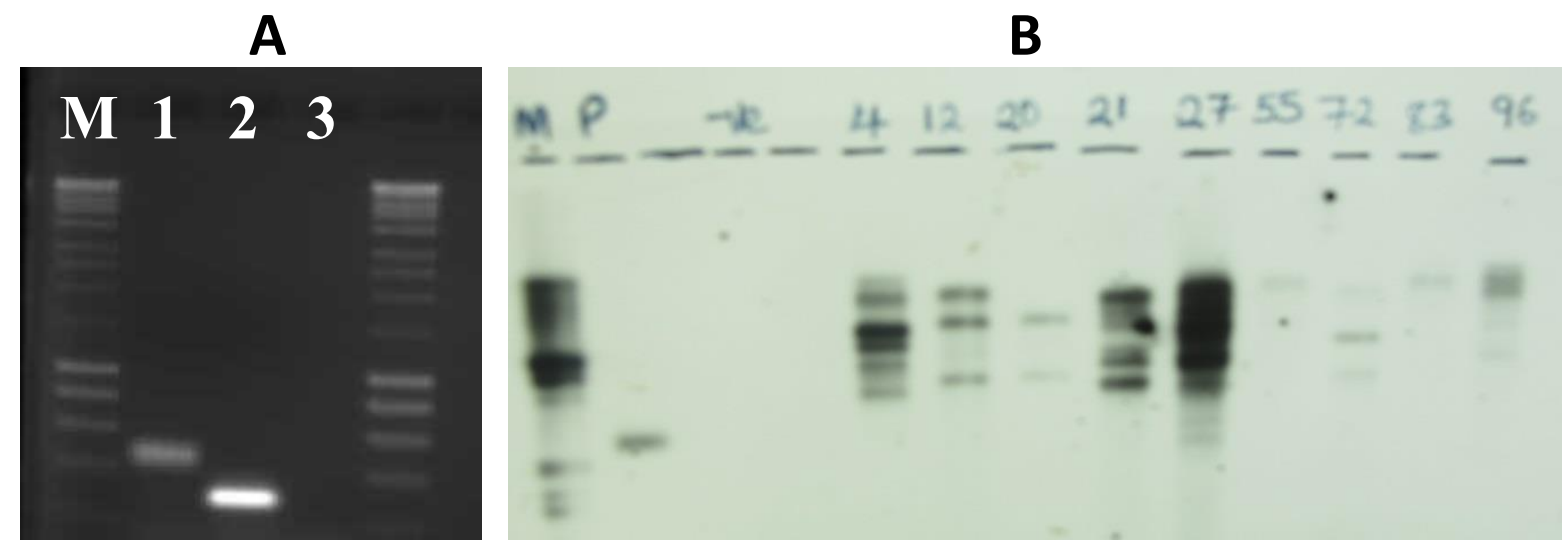

Figure 4. Probe labeling and southern blot analysis of selected transgenic lines. A: DIG label PCR probe using plasmid mCed-9. M) Molecular weight marker. 1. Labeled mCed9 2. Un-labeled mCed9. 3. Water control. B: Southern analysis of transgenic lines: M) DIG labeled marker. P) Plasmid pYC11. -ve) is un-transformed Sukali Ndiizi plant. 4, 12, 20, 21, 27, 55, 72, 83, 96 are transgenic lines.

Table 1. Disease severity index (DSI) of control plants infected with different inoculum concentrations.

\begin{tabular}{|c|c|c|c|c|}
\hline Cultivar & Symptom & $\begin{array}{l}\text { Treatment } 1 \\
\left(2 \times 10^{4} \text { spores } \mathrm{ml}^{-1}\right)\end{array}$ & $\begin{array}{l}\text { Treatment } 2 \\
\left(2 \times 10^{6} \text { spores } \mathrm{ml}^{-1}\right)\end{array}$ & $\begin{array}{l}\text { Treatment } 3 \text { (5 agar } \\
\text { stabs) }\end{array}$ \\
\hline \multirow{3}{*}{ Sukali Ndiizi } & Yellowing & 2.9 Susceptible & 3.9 Highly susceptible & 3.1 Highly susceptible \\
\hline & Wilting & 1.4 Tolerant & 2.2 Tolerant & 2.5 Tolerant \\
\hline & Corm discolouration & 5.2 Highly susceptible & 6.4 Highly susceptible & 5.4 Highly susceptible \\
\hline \multirow{3}{*}{ Nakinyika } & Yellowing & 2.0 Tolerant & 1.0 Resistant & 1.4 Tolerant \\
\hline & Wilting & 1.4 Tolerant & 1.2 Tolerant & 1.6 Tolerant \\
\hline & Corm discolouration & 1.0 Resistant & 1.4 Tolerant & 1.0 Resistant \\
\hline
\end{tabular}

Scale for the leaf index (yellowing and wilting): Resistant = 1, Tolerant 1.1-2.0, Susceptible 2.1-3.0 and highly susceptible 3.1-4.0. Scale for corm discolouration: Resistant = 1, Tolerant 1.1-3.0, Susceptible 3.1-5.0 and highly susceptible 5.1-8.0.

$2 \times 10^{6}$ spores $\mathrm{ml}^{-1}$ (Table 1 ). Table 1 shows the computed disease severity index (DSI) values for the yellowing, wilting and corm discolouration, 8 weeks after infection. Corm discolouration was found to be the best indicator for assessing disease susceptibility and tolerance since wilting and yellowing was giving variable responses (Figure 5). All deductions that were later made were based on corm discolouration responses. Nakinyika was confirmed resistant and Sukali Ndiizi susceptible therefore the Foc race 1 isolate used in this study was considered pathogenic to Sukali Ndiizi and was subsequently used in assessing the transgenics.

\section{Determination of Foc race 1 inoculum for consistent infection}

To evaluate the best inoculum (spores or mycelia), thirty plants each of Sukali Ndiizi and Nakinyika were infected with $250 \mathrm{~g}$ of millet pre-infected with 2 different concentrations of fungus spore suspensions $(50 \mathrm{ml}$ of fungal suspension containing $2 \times 10^{4}$ and $2 \times 10^{6}$ spores $\mathrm{ml}^{-1}$ ) or with 5 mycelium-covered agar stabs. Infected plants were observed for eight weeks. Sukali Ndiizi leaves showed yellowing two weeks after infection as compared to Nakinyika which showed milder yellowing but only after 4 weeks. Sukali Ndiizi plants infected with millet with $2 x$ $10^{6}$ spores $\mathrm{ml}^{-1}$ and 5 agar stabs treatments were comparable for yellowing after 2 weeks and for wilting after 4 weeks. For the wilting and corm discolouration symptoms, all the treatments showed the same level of responses in Sukali Ndiizi after 8 weeks. However DSI values obtained for Sukali Ndiizi from millet treatment with $2 \times 10^{4}$ spores $\mathrm{ml}^{-1}$ were low (Table 1 ) in all cases compared with the other two treatments, indicating that the results with that inoculum were not the best indicators in the small pot assay. Furthermore, in treatment using 2 x $10^{6}$ spores $\mathrm{ml}^{-1}$, Nakinyika a cultivar known to be resistant to Foc race 1 showed some infection, indicating that the inoculum concentration was much higher than 

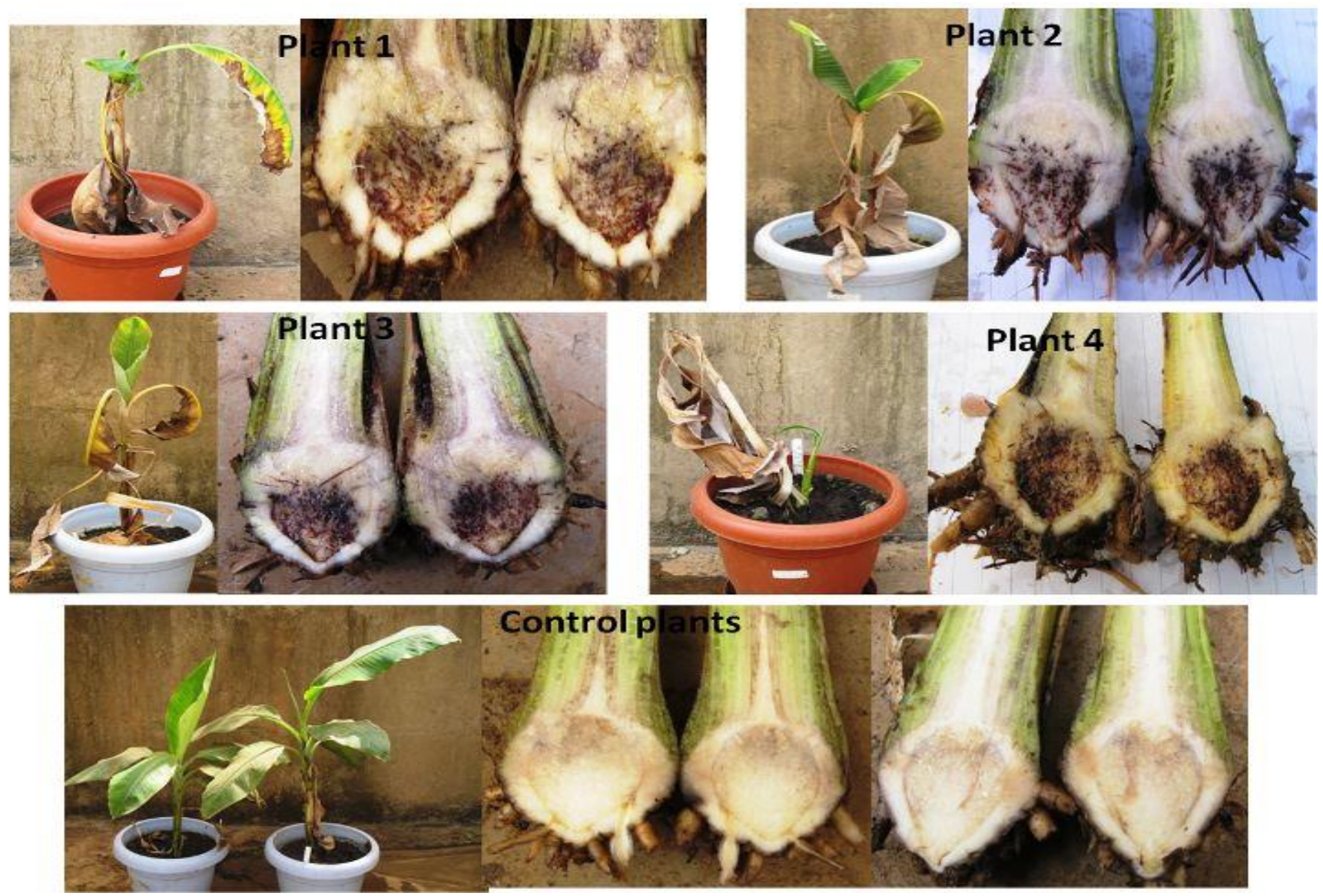

Figure 5. Representative picture showing internal and external symptoms of plants. Tissue culture derived plants at 8 weeks after infection. Plants 1, 2, 3 and 4 are Sukali Ndiizi cultivar and control plants are Nakinyika cultivar.

the one to which plants are normally exposed in the field (Table 1). Therefore, instead of spores, millet infected with five mycelium-covered agar stabs was selected as a method of inoculation for all subsequent infection experiments.

\section{Evaluating the reaction of transgenics to Foc race 1 infection}

Twenty-eight transgenic lines of Sukali Ndiizi with 5 to 10 replicates each were inoculated with $250 \mathrm{~g}$ of millet infected with Foc race 1 using fivemycelium-coated agar stabs. Scores for external symptoms were recorded after 6,8 weeks and 13 weeks. External symptoms were clearly visible six weeks after infection and intensified with increase in the duration of exposure to the fungus. By thirteen weeks, most lines showed variability in the level of susceptibility to Foc race 1 infection for all the symptoms, that is, yellowing $(p<0.001)$, wilting $(p<$ $0.001)$ and corm discolouration $(p<0.001)$. When all the mean symptom scores were subjected to Dunnett's test, six lines were found to be significantly different from the infected control plants based on the corm discolouration $(p<0.001)$. Line 27 had the lowest mean symptom score for both external and internal symptoms and the corm was almost symptom free (Table 2).

Based on the mean symptom score for corm discolouration, the transgenic lines were placed into three categories of disease severity (Figure 6). Lines 27, 72 and 83 were classified as tolerant, 12, 37, 55 and 96 as susceptible while the rest as highly susceptible to Foc race 1 infection. Within each transgenic line, the clones that showed any degree of infection were counted. Four lines had 2 or less clones infected, two lines had 3 clones while the rest had more than5 clones with corm discoloration symptoms.

\section{DISCUSSION}

\section{Generating Fusarium resistant lines}

Options for the control of Fusarium wilt are limited and there is lack of commercially suitable resistant cultivars. Hence, the introduction of resistance genes into banana 
Table 2. Disease severity index (DSI) of transgenic lines 13 weeks after Foc race 1 infection.

\begin{tabular}{|c|c|c|c|c|}
\hline \multirow{2}{*}{$\begin{array}{c}\text { Transgenic line } \\
\text { numbers }\end{array}$} & \multirow{2}{*}{$\begin{array}{l}\text { Number of } \\
\text { clones }\end{array}$} & \multicolumn{3}{|c|}{ Mean symptom scores } \\
\hline & & Yellowing & Wilting & Corm discoloration \\
\hline 4 & 8 & 4.5 & 4.6 & 7.5 \\
\hline 5 & 7 & 3 & 3.1 & 6.3 \\
\hline 6 & 6 & 4.2 & 4 & 6 \\
\hline 8 & 10 & 3.8 & 3.9 & 6.5 \\
\hline 9 & 6 & 3 & 3.2 & 5.5 \\
\hline 11 & 10 & 3.6 & 3.9 & 6.6 \\
\hline 12 & 6 & 2 & $2.5^{\star}$ & $3.1^{*}$ \\
\hline 14 & 7 & 2.7 & 2.7 & 5.7 \\
\hline 21 & 7 & 3.9 & 3.9 & 7.1 \\
\hline 27 & 7 & $1.5^{\star}$ & $1.8^{\star}$ & $2.3^{*}$ \\
\hline 28 & 8 & 4.5 & 4.8 & 7.6 \\
\hline 30 & 10 & 3.4 & 3.5 & 6.5 \\
\hline 31 & 8 & 2.5 & 3.1 & 5.4 \\
\hline 33 & 6 & 2.8 & 3.3 & 6.2 \\
\hline 37 & 5 & $1.2^{*}$ & $2.0^{*}$ & 4.4 \\
\hline 39 & 8 & 3.8 & 3.6 & 6.5 \\
\hline 46 & 5 & 3.3 & 3.7 & 6.3 \\
\hline 48 & 7 & 4 & 4.1 & 7.1 \\
\hline 53 & 8 & 3.8 & 3.9 & 6.6 \\
\hline 55 & 7 & 2.3 & 2.4 & $3.7^{*}$ \\
\hline 61 & 7 & 3.4 & 3.7 & 6 \\
\hline 65 & 8 & 4.4 & 4.9 & 6.1 \\
\hline 66 & 9 & 3.6 & 3.8 & 6.4 \\
\hline 72 & 7 & $1.9^{*}$ & $2.1^{*}$ & $2.4^{\star}$ \\
\hline 80 & 7 & 4.9 & 4.9 & 6 \\
\hline 83 & 9 & $1.8^{*}$ & $2.1^{*}$ & $2.4^{\star}$ \\
\hline 96 & 6 & 2 & 2.5 & $3.5^{\star}$ \\
\hline 99 & 7 & 2.6 & 2.7 & 6.3 \\
\hline Infected control & 5 & 4.6 & 4.8 & 7.6 \\
\hline
\end{tabular}

*Denotes lines that are significantly different from the non-transgenic control plants. Differences were considered significant at $P<0.05$.

plants via biotechnological means is one of the ways for developing resistant banana cultivars. Previously, recalcitrance to transformation hindered the attempts towards introducing novel traits in banana (Ganapathi et al., 2001). However, the transformation and regeneration frequencies of several banana cultivars have been improved over the years (Khanna et al., 2004; Arinaitwe, 2008). The results obtained in this study further demonstrate the capacity of our laboratory to successfully transform banana cultivars using $A$. tumefaciens and male flower derived embryogenic cell suspensions. The Agrobacterium mediated method has been used to develop traits like resistance to banana bacterial wilt disease (Leena et al., 2010) and stimulation of the banana cell cycle (Talengera et al., 2012).

Genetic engineering to enhance antifungal resistance through over-expression of various transgenes has emerged as a very promising strategy and has been tested in many crop plants. Strategies like expressing Rgenes, pathogenesis-related (PR)/antimicrobial genes, detoxification of pathogen virulence factors, increasing structural barriers, and the modification of defencesignalling pathways have been used to produce transgenic plants (Grover and Gowthaman, 2003). The use of RNAi technology has also shown survival of transgenics after infection which is attributed to the down regulation of $F$. oxysporum genes (Hu et al., 2015). There are however, no current commercially available transgenic plant species with increased resistance towards fungal pathogens (Wally and Punja, 2010). There are an increasing number of examples of plant-pathogen interaction strategies that result in control of cell death. We have previously reported in Australia that nematode anti-apoptosis gene Ced9 can be expressed in 'Lady 


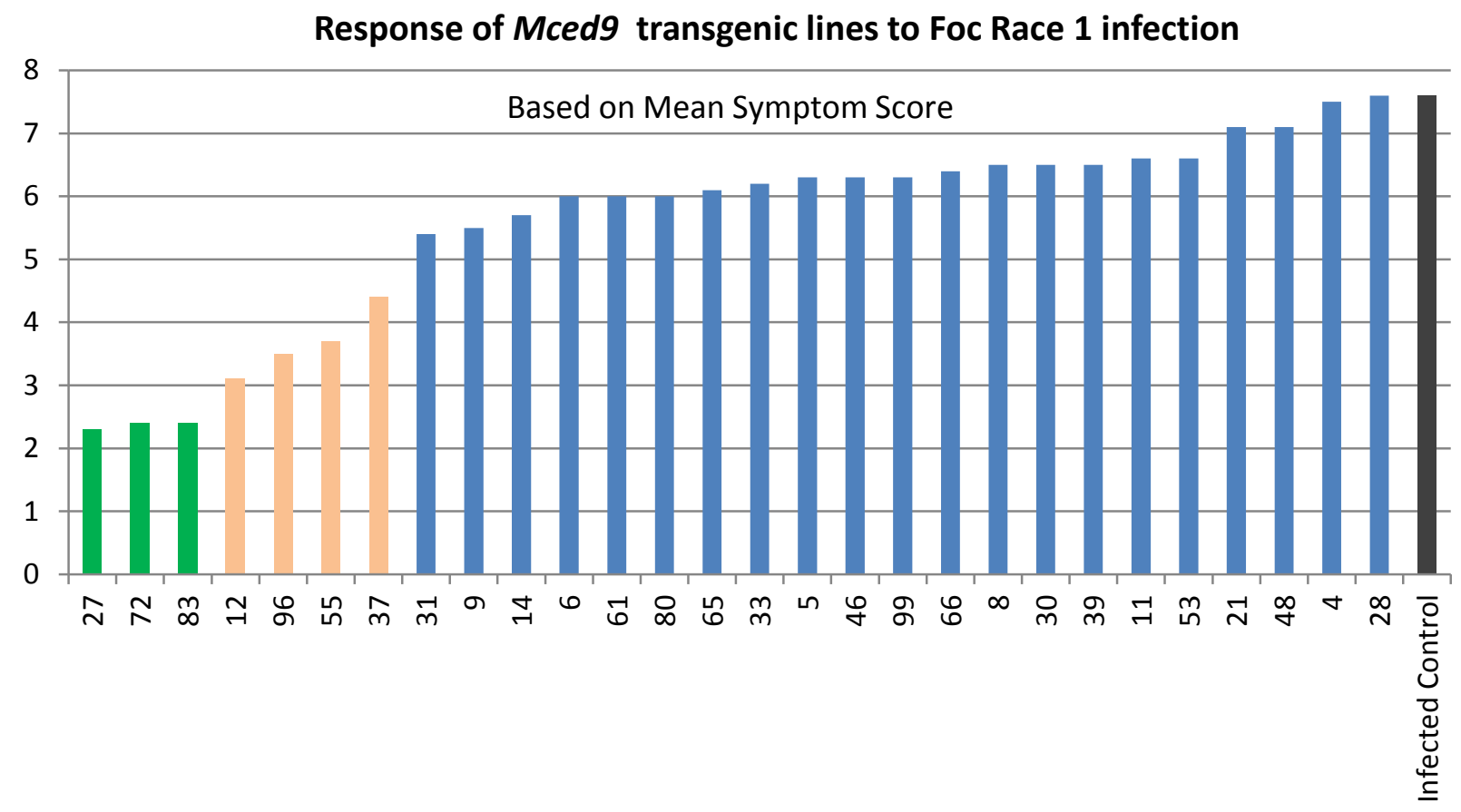

Figure 6. Levels of disease severity shown by the $\mathrm{mCed} 9$ transgenic lines after Foc race 1 infection. The disease severity index of transgenic lines showing the three disease levels: Tolerant, susceptible $(12,37,55,96)$ and highly susceptible $(4,5,6,8,9,11,14,21,28,30,33,39,46,48,53,61,65,66,80,99)$.

Finger' $(A A B)$ banana to generate resistance to Foc race1 (Paul et al., 2011 ). A plant codon optimized version of Ced9 (mCed9) was therefore expected to confer Foc race 1 resistance to 'Sukali Ndiizi', an $A A B$ banana cultivar from East Africa and the results obtained further confirmed the potential for cell death inhibition in plant protection against pathogens.

In this study, transformation of Sukali Ndiizi with mCed9 was successfully achieved and a large number of independent transgenic lines were obtained and characterised. Generally, for stable transgene expression, lines with a single copy are preferred and several studies have shown that transgenics generated using Agrobacterium-mediated transformation system have lower transgene insertions with high frequencies of single transgene copy. In this study, the transgenic lines generated had copy number ranging from single to multiple and there was not found any direct correlation between copy number and Foc tolerance. The three best lines had variable copy transgene number.

\section{Small plant bioassay and Foc inoculations}

Fusarium infects the banana plant though the roots and the fungal hyphae adhere to the host root surface before fungal infection commences. The pathogen moves through the root parenchyma tissue until it reaches the vascular tissue and blocks the xylem vessels (Mai and
Abawi, 1987) causing a reddish-brown discoloration of the corm and pseudostem. Wilting symptoms observed are the combined result of fungal spores and mycelium blocking the xylem, toxin production, and host defence responses such as tyloses, gums and gels (Beckman and Roberts, 1995). Leaves of infected banana plants eventually become bright yellow, before they wilt and collapse around the pseudostem.

The two-month-old plantlets $(10-15 \mathrm{~cm}$ tall) that were used to screen for Foc tolerance were found to be suitable and the pathogenicity of the inoculum used was confirmed using known resistant and susceptible cultivars. As expected, East African Highland banana cultivar 'Nakinyika' showed high tolerance to Fusarium wilt, while 'Sukali Ndiizi' was susceptible. All inoculated, susceptible plants showed both foliage and corm symptoms within the 13 weeks of trial, whereas the noninoculated plants remained symptom-free.

Different infection methods have previously been used for screening banana plants with Fusarium wilt. These include immersion of roots in spore suspensions of known concentrations or use of a substrate like Fumonisin. The present study used millet grain which favours spore multiplication and survival of the fungus (Smith et al., 2008). Although even resistant plants can get infected if very high fungal inoculum load is used and they can show some foliar symptoms, however, corm damage occurs only in susceptible lines. Infection using different forms of Foc race1 inoculum with Sukali Ndiizi and 
Nakinyika proved that better consistency is obtained when mycelium-covered agar stabs are used to infect millet grain as compared to the spore suspensions. In other studies with other cultivars, infections have been achieved with spore suspensions (Pei et al., 2005; Mahdavi et al., 2012; Wei-ming et al., 2011). However, there are differences in the proportion of different spore types (macroconidia, microconidia and chlamydospores) that different fungal isolates produce even when they belong to the same race (Groenewald et al., 2006). The proportion of spore types present in the infection culture affects the virulence of the fungus. The agar stabs predominantly contain mycelium which could be a reason for better infection since the mycelium is responsible for nutrient absorption, quick colonisation and hence quick multiplication of the fungus.

The internal and external glass house symptoms in this study showed 4 to 8 weeks after infection as opposed to field conditions where symptoms start becoming visible only after 5 to 6 months of infection. Field conditions have the limitations of being costly due to the need for space, lot of man power and the requirement for strict quarantine. The field environment, usually has factors affecting disease expression such as inoculum concentration, temperature and other variables that are difficult to control they are highly effective and reliable method for screening resistant lines.

An alternative method is to first screen a large number of lines using young plantlets in the glasshouse, under controlled conditions and using measured inoculum and pathogenicity tested races of Foc.

\section{Assessing Fusarium wilt tolerance}

Data analysis, which included yellowing, wilting and corm discolouration, showed variable Foc disease responses among the tested transgenic lines. The evaluated transgenic lines were categorized as tolerant, susceptible or highly susceptible, according to how they responded to the fungal infection (Table 1) based on scoring ranges by Mak et al. (2001). Three lines showed tolerance and four lines showed low susceptibility whereas the rest of the lines were almost as susceptible as the wild type controls. When the transgenic plants were compared statistically with the infected non-transgenic plants, lines $12,2755,72,83$ and 96 were significantly better than the control plants $(p<0.001)$. Similar observations have been previously reported in tobacco expressing Ced9 with the level of resistance displayed ranging from highly tolerant to completely resistant after $S$. sclerotiorum infection (Dickman et al., 2001).

For pathogenicity studies, the number of infected clones of a given line can also be considered indicative of the level of susceptibility. Lines with less than 3 infected clones are better indicators of resistance than those with a large number of clones showing infection. Four lines had only 1 or 2 clones that showed severe corm damage after Foc race 1 infection. Of these lines, two (line 27 and 72) were only mildly affected by Foc race 1 infection. Since all the infected transgenic lines were PCR checked, the variable response levels among these transgenic lines could be due to the different integration patterns that could have occurred for each line. Variation in expression and stability which is reported to be caused by environmental effects, promoter methylation, inter-loci interactions and gene silencing can also be responsible for the differences observed (Marenkova et al., 2012). The lines generated as part of this study were evaluated for a single growth cycle and the performance of these genes in ratoon crops was not assessed. For assessing long term transgene expression stability, these lines should be evaluated in the field for at least up to the $10^{\text {th }}$ ratoon crop.

\section{Transgene choice-m Ced9}

Genes that target the pathogen itself or neutralise the pathogen derived metabolites are being exploited in many crops for providing resistance to Foc in susceptible cultivars. Two lines of a susceptible banana cultivar transformed with a plant ferrodoxin like protein $(\mathrm{flp})$ gene resulted in 14.2 and $20.8 \%$ disease severities compared to the wild type which had $41.6 \%$ after Foc 4 infection (Mei et al., 2011). Similarly, transgenic Pisang Nangka cultivar with the rice thaumatin-like protein (t/p) had disease incidence of $29.4 \%$ compared to the control plant which had $89.1 \%$ after 4 weeks of infection (Mahdavi et al., 2012). Although such genes like the thaumatin-like protein have shown lower disease severities compared to the control plants, the necrotrophic nature of $F$. oxysporum demands for a better resistance strategy that would prevent the fungus from killing the plant cells even after infection. Such a strategy will provide more sustainable Fusarium wilt resistance. Anti-apoptosis genes that are able to prevent cell death after infection have shown promising protection in tomatoes, tobacco and banana when challenged with various pathogens (Dickman et al., 2001; Ping et al., 2004; Paul et al., 2011). In the present study, the effect of Foc race 1 infection on transgenic Sukali Ndiizi banana containing the plant-codon optimised synthetic version of a nematode anti-apoptosis gene Ced9 was evaluated. Even though Ced9 was previously used for 'proof-ofconcept' that it can confer Foc race 1 tolerance to bananas, we have also been aware of the possible regulatory problems related to using a nematode gene for product development. Consequently, we designed a synthetic mCed9 (modified Ced9) gene with the same amino-acid sequence as Ced-9 but with altered DNA sequence using plant-preferred codons.

Although many animal anti-apoptosis genes have been shown to prevent cell death and confer biotic and abiotic 
stress tolerance to plants (Dickman et al., 2001; Paul et al., 2011), the mode of action of anti-apoptosis genes in plants is not clearly known. Bcl-2 3'UTR has previously been shown to protect plant cells from biotic and abiotic stress (Dickman et al., 2001) and some studies have indicated that microRNAs, e.g. miR-7 regulate the expression of anti-apoptosis gene Bcl-2 through direct 3'UTR interactions (Xiong et al., 2011), in this study, we started with the hypothesis that in case of Ced9, it is probably the anti-apoptosis protein and not the DNA/RNA sequences that are involved in generating fungal resistance in the transgenics. This hypothesis was confirmed in this study because 'Sukali Ndiizi' mCed9 transgenics showed Foc race1 tolerance similar to Ced9 transgenics of 'Lady Finger'.

Animal derived anti-apoptosis genes have shown promising protection in plants when challenged with various pathogens. The human $\mathrm{BCl}-2$, nematode $\mathrm{Ced} 9$ and baculovirus op-iap were all able to control $\mathrm{S}$. sclerotiorum in transgenic tobacco (Dickman et al., 2001), while the human $B c l-x L$ and nematode Ced9 genes increased tolerance of tomato to cucumber mosaic virus (Ping et al., 2004). Such findings suggest that the products of these anti-apoptosis genes interact with the natural homologues present in plants. Furthermore, some plant Pathogen Related $(P R)$ genes and $R$ genes in plants have been found to be closely related to mammalian Apaf ${ }^{1}$ and the nematode ced4 which genes are known to be regulators of programmed cell death. Recently, it has also been found that the products of these genes (Apaf ${ }^{1}$, Ced 4 and plant $R$ gene) also share amino-terminal effector domains which could further show homology (Christina and Arunika, 2012). Some Bcl2 associated anthanogenes (BAG) have been found (Juqiang et al., 2003) and in Arabidopsis, eight BAG genes have been identified and the AtBAG6 gene is associated with reduced disease development in $B$. cinerea (Kabbage and Dickman, 2008). In a recent study where native banana genes MusaDAD1, MusaBAG1 and MusaBl1 were used, only MusaBAG1 showed high levels of resistance to Foc 1 (Ghag et al., 2014). It is therefore possible that plant protection via cell death inhibition in naturally resistant plants occurs through BAG genes which interfere with the products of $R$ genes and pathogenesis related proteins to eventually prevent death of cells.

\section{Conclusions}

The results obtained in this study further demonstrate the capacity to successfully transform 'Sukali Ndiizi' cultivar and other elite cultivars using $A$. tumefaciens and male flower derived embryogenic cell suspensions. Modified $C$. elegans $\mathrm{mCed} 9$ gene driven by maize ubiquitin promoter expressed in the transgenics generated could provide significant protection to at least three transgenic Sukali
Ndiizi lines against Fusarium wilt. These lines can now be multiplied and evaluated in a disease screening trial in the field with reference cultivars for resistance and tolerance included.

Although this study used a plant codon optimised synthetic gene of nematode origin successfully, using genes of plant origin like the BAG genes would be preferable for purposes of public acceptance (Enoch et al., 2011; Ghag et al., 2014). Identification and isolation of other sequence homologues of the genes involved in programmed cell death can be exploited for generating Fusarium wilt resistant banana cisgenics.

\section{Conflict of Interests}

The authors have not declared any conflict of interests.

\section{ACKNOWLEDGEMENTS}

This work was supported by the Bill and Melinda Gates Foundation through the Biofortification project at National banana research program, Uganda and Queensland University of technology, Australia.

\section{Abbreviations}

CTAB, Cetyltrimethylammonium bromide; PCR, polymerase chain reaction; RT-PCR, reverse transcription - polymerase chain reactions; dNTPs, deoxynucleoside 5'-triphosphates; DNA, deoxyribonucleic acid; cDNA, complementary DNA; PDA, potato dextrose agar; LSI, leaf symptom index; RDI, corm discolouration index; DSI, disease severity index; ANOVA, analysis of variance.

\section{REFERENCES}

Arinaitwe G (2008). Improved Agrobacterium - mediated Transformation Methods for Banana and Plantain. (Unpublished doctoral dissertation) Catholic University of Leuven, Belgium.

Becker DK, Dugdale B, Smith MK, Harding RM, Dale J (2000). Genetic transformation of Cavendish banana (Musa spp. AAA group) $\mathrm{cV}$ 'Grand Nain' via micro-projectile bombardment. Plant Cell Rep. 19:229-234.

Beckman CH, Roberts EM (1995). On the nature and genetic basis for resistance and tolerance to fungal wilt diseases of plants. Adv. Bot. Res. 21:35-77.

Christina EN, Arunika H (2012). Programmed cell death in C. elegans, mammals and plants. Eur. J. Cell Biol. 91:603-613.

Collinge DB, Jorgensen HJ, Lund OS, Lyngkjaer MF (2010). Engineering pathogen resistance in crop plants: current trends and future prospects. Annu. Rev. Phytopathol. 48:269-291.

Dickman MB, Park YK, Oltersdorf T, Li W, Clemente T, French R (2001). Abrogation of disease development in plants expressing animal anti-apoptotic genes. Proc. Natl. Acad. Sci. USA. 98:69576962.

Enoch KM, Justus W, Jose FZ (2011). Attitudes, perceptions, and trust. Insights from a consumer survey regarding genetically modified banana in Uganda. Appetite 57:401-413. 
Ganapathi R, Higgs NS, Balin-Kurti PJ, Arntzen CJ, May GD,Van JM (2001). Agrobacterium-mediated transformation of embryogenic cell suspensions of the banana cultivar Rasthali (AAB ). Plant Cell Rep. 20:157-162.

Gaolathe R, Arunika GH (2015). Programmed cell death: genes involved in signaling, regulation, and execution in plants and animals. Botany 93(4):193-210.

Ghag SB, Shekhawat UKS, Ganapathi TR (2014). Native cell-death genes as candidates for developing wilt resistance in transgenic banana plants. AoB Plants 6:plu037.

Girhepuje PV, Shinde GB (2011). Transgenic tomato plant expressing a wheat endochitinase gene demonstrate enhanced resistance to Fusarium oxysporum f. sp. Iycopersici. Plant Cell Tissue Organ Cult. 105(2):243-251.

Groenewald S, Berg NVD, Marasas WFO, Viljoen A (2006). Biological, physiological and pathogenic variation in a genetically homogenous population of Fusarium oxysporum f.sp. cubense. Australas. Plant Pathol. 35:401-409.

Grover A, Gowthaman R (2003). Strategies for development of fungusresistant transgenic plants. Curr. Sci. India 84:330-340.

Hu Z, Parekh U, Natsumi M, Trusov Y, Botella JR (2015). Down regulation of Fusarium oxysporum endogenous genes by Host Delivered RNA interference enhances disease resistance. Front. Chem. 3:1.

Juqiang Y, Cixin H, Hong Z (2003). The BAG-family proteins in Arabidopsis thaliana. Plant Sci.165:1-7.

Kabbage M, Dickman MB (2008). The BAG proteins: a ubiquitous family of chaperone regulators. Cell. Mol. Life Sci. 65:1390-1402.

Kangire A, Rutherford MA, Gold CS (2001). Distribution of Fusarium wilt and the population of Fusarium oxysporum f.sp. cubense on bananas in Uganda. In: Proceedings of International Workshop on the Banana Fusarium Wilt Disease Genting Highlands Resort, Malaysia: INIBAP, Montpellier. pp. 152-161.

Khanna H, Becker D, Kleidon J, Dale J (2004). Centrifugation Assisted Agrobacterium tumefaciens-mediated Transformation (CAAT) of embryogenic cell suspensions of banana (Musa spp. Cavendish AAA and Lady finger AAB). Mol. Breed. 14:239-252.

Khanna HK, Paul JY, Harding RM, Dickman MB, Dale JL (2007). Inhibition of Agrobacterium-induced cell death by antiapoptotic gene expression leads to very high transformation efficiency of banana. Mol. Plant Microbe Interact. 20:1048-1054.

Leaky ALC (1970). Diseases of bananas. Oxford University Press.

Leena T, Henry M, Jaindra NT, Wilberforce TK (2010). Expression of sweet pepper Hrap gene in banana enhances resistance to Xanthomonas Campestris pv. musacearum. Mol. Plant Pathol. 11:721-131.

Mahdavi F, Sariah M, Maziah M (2012). Expression of Rice ThaumatinLike Protein Gene in transgenic banana plants enhances resistance to Fusarium Wilt. Appl. Biochem. Biotechnol. 166:1008-1019.

Mai WF, Abawi GS (1987). Interactions among Root-Knot Nematodes and Fusarium-Wilt Fungi on Host Plants. Annu. Rev. Phytopathol. 25:317-338.

Mak C, Mohamed AA, Liew KW, Ho YW (2001). Early screening technique for Fusarium wilt resistance in banana micropropagated plants. In: Banana Improvement: Cellular, Molecular Biology, and Induced Mutations. (Jain SM and Swennen R eds). Leuven, Belgium: Science Publishers, Inc Enfield, USA. pp. 219-227.

Marenkova TV, Loginova DB, Deineko EV (2012). Mosaic Patterns of Transgene Expression in Plants. Russ. J. Genet. 48:293-306.

Mei KY, Sin WL, Kuei CS, Yi-Hsien L, Chen TY, Teng YF (2011). An easy and efficient protocol in the production of pflp transgenic banana against Fusarium wilt. Plant Biotechnol. Rep. 5:245-254.
Mohandas S, Sowmya HD, Saxena AK, Meenakshi S, Thilaka Rani R, Mahmood R (2013)Transgenic Banana cv. Rasthali (AAB, Silk gp)harboring Ace-AMP1 gene imparts enhanced resistance to Fusarium oxysporum f.sp.cubense race 1. Sci. Hortic. 164:392-399.

Namanya P, Magambo SM, Mutumba G, Tushemereirwe W (2004). Somatic embryogenesis from immature male inflorescences of East African Highland Banana CV "Nakyetengu". Afr. Crop Sci. J. 12:4349.

Paul JY, Becker KD, Dickman BM, Harding MR, Khanna KH, Dale J L (2011). Apoptosis-related genes confer resistance to Fusarium wilt in transgenic 'Lady Finger' bananas. Plant Biotechnol. 9:1141-1148.

Pei XW, Chen SK, Wen RM, Ye S, Huang JQ, Zhang YQ (2005). Creation of Transgenic Bananas Expressing Human Lysozyme Gene for Panama Wilt Resistance. J. Integr. Plant Biol. 47:971-977.

Ping X, Rogers SJ, Roossinck MJ (2004). Expression of anti-apoptotic genes $b c l-x L$ and ced- 9 in tomato enhances tolerance to viralinduced necrosis and abiotic stress. In: Plant Biology Division, the Samuel Roberts Noble Foundation, Ardmore, OK 73401. Communicated by George Bruening. University of California Davis CA. pp. 15805-15810.

Ploetz RC (2006). Fusarium wilt of banana is caused by several pathogens referred to as Fusarium oxysporum $f$. $s p$ cubense. Phytopathology 96:653-656.

Ploetz RC (2015). Fusarium wilt of banana. Phytopathology 105:15121521.

Ploetz RC, Pegg KG (2000). Fusarium wilt in Jones, DR (ed) CABI Wallingford UK.

Punja ZK (2001). Genetic engineering of plants to enhance resistance to fungal pathogens - a review of progress and future prospects. Can. J. Plant Pathol. 23:216-235.

Smith LJ, Smith MK, Tree D, OKeefe D, Galea VJ (2008). Development of a small-plant bioassay to assess banana grown from tissue culture for consistent infection by Fusarium oxysporum f.sp. cubense. Australas. Plant Pathol. 2:171-179.

Talengera D, Beemster GTS, Tushemereirwe WK, Kunert K (2012). Isolation and characterisation of a banana $C y c D 2 ; 1$ gene and its over-expression enhances root growth. Afr. J. Biotechnol. 11:1032810339.

Tushemereirwe WK, Karamura DA, Sali H, Bwamiki D, Kashaija I, Nankinga C (2001). Bananas (Musa spp.) In: Agriculture in Uganda (Crops). (Mukiibi J ed). Fountain Publishers, Kampala.

Van Asten PJA, Florent D, Apio MS (2008). Opportunities and constraints for dried dessert banana export in Uganda. International Conference on Banana and Plantain in Africa: Harnessing International Partnerships to Increase Research Impact. Mombasa, Kenya: Acta Hort. (ISHS). pp. 105-112.

Wally O, Punja ZK (2010). Genetic engineering for increasing fungal and bacterial disease resistance in crop plants. GM Crops 1:199-206.

Wei-ming L, Chun-mei Q, Yi-Wei M, Yu-lin H, Jiang-Hui X (2011). Tolerance of banana for Fusarium wilt is associated with early $\mathrm{H}_{2} \mathrm{O}_{2}$ accumulation in the roots. J. Biotechnol. 55(10):11378-11387.

Xiong SD, Zheng YJ, Jiang P, Liu RH, Liu XMChu YW (2011). MicroRNA-7 Inhibits the Growth of Human Non-Small Cell Lung Cancer A549 Cells through Targeting BCL-2. Int. J. Biol. Sci. 7:805814. 